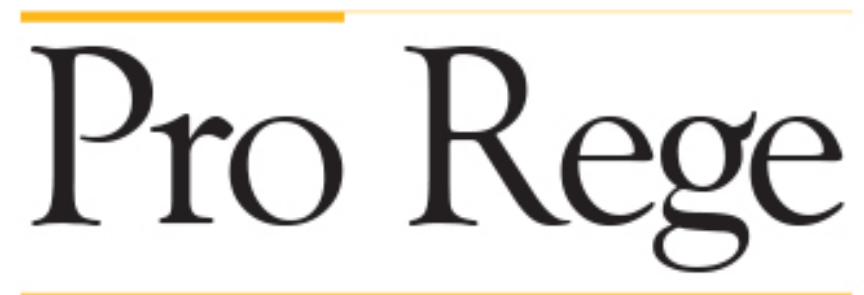

Volume 11 | Number 2

Article 4

December 1982

\title{
Toward a Shared Understanding of the Arts
}

\section{Lambert Zuidervaart}

Follow this and additional works at: https://digitalcollections.dordt.edu/pro_rege

Part of the Art and Design Commons, Christianity Commons, and the Higher Education Commons

\section{Recommended Citation}

Zuidervaart, Lambert (1982) "Toward a Shared Understanding of the Arts,"

Pro Rege: Vol. 11: No. 2, 18 - 25.

Available at: https://digitalcollections.dordt.edu/pro_rege/vol11/iss2/4

This Feature Article is brought to you for free and open access by the University Publications at Dordt Digital Collections. It has been accepted for inclusion in Pro Rege by an authorized administrator of Dordt Digital Collections. For more information, please contact ingrid.mulder@dordt.edu. 


\title{
Toward A Shared Understanding of the Arts
}

Lambert Zuidervaart

\begin{abstract}
Lambert Zuidervaart, a graduate of Dordt College and the Institute for Christian Studies in Toronto, Ontario, received his doctorate from the Free University in Amsterdam, The Netherlands. Currently he is Assistant Professor of Interdisciplinary Studies at The King's College, Edmonton, Alberta. The following article is adapted from a speech he presented, in May 1982, at the Arts Seminar sponsored by the Fine Arts Division of the Dordt College Faculty.
\end{abstract}

\section{Introduction}

The first question discussed in Dordt's Arts Seminar needs some introductory interpretation. When we ask "What are the minimum common understandings we need in order to discuss the nature of art?" we should understand what we are trying to find out.

I do not think this question is meant to imply that our discussion can only occur on the basis of certitudes that can be known directly, without inference. If the question does imply the need for such foundational certitudes, then we should re-examine the foundationalist theory of theorizing discussed in Wolterstorff's Reason within the Bounds of Religion. ${ }^{I}$

Again, I do not think the question implies that our discussion can be worthwhile only to the extent that we already share the same socio-historical context, way of life, perspective, methods, and concepts. If the question does imply the need for an initial consensus, then we should re-examine the claims of common sense and the attendant problems of relativism. ${ }^{2}$

It makes little difference whether "we" are simply the persons in the same room or are all those persons interested in discussing the 
nature of art. In either case, and in any case, the discussion could never begin if it had to presuppose self-evident certitudes or an achieved consensus about the nature of art. It is obvious, however, that, despite a lack of basic axioms and of broad consensus, the discussion is well underway not only at Dordt College but also in the history of Western society.

That is the first matter we need to understand, not in order to discuss, but as we discuss art. Though conversations about art might move us toward a shared understanding, no common understandings are needed in order to discuss the nature of art. We might need patience, intelligence, creativity, an ability to solve problems, or developed interests. But a common understanding we do not need, at least not in order to begin.

A movement toward a shared understanding will bring us in the vicinity of four issues having contemporary interest and a long history. They are the problem of defining art, the place of art in history and society, meaning and truth in the arts, and the processes of artistic and aesthetic education. In this article I shall concentrate on some philosophical definitions of art and the roles of art in society. My method will be to comment on recent writings by Calvin Seerveld and Nicholas Wolterstorff.

\section{Problems in Defining Art.}

According to George Dickie, "the questions included within the field of aesthetics have developed out of twin concerns in the history of thought: the theory of beauty and the theory of art." ${ }^{13}$ But the more precise origins of aesthetics can be located in developments during the eighteenth century. Via discussions of taste, the theory of beauty began to be superseded by a theory of the aesthetic. Through the complex process sketched by Kristeller, poetry, music, architecture, sculpture, and painting began to be grouped together as core members of a class called "art," "fine art," or "beaux arts."4
And, as Saisselin has argued, philosophers began seriously "to introduce new philosophical concepts into the realm of taste and the fine arts," often to the linguistic confusion of far too many amateurs and art critics and to the aesthetic edification of all too few practicing artists and connoisseurs. ${ }^{5}$

It is no coincidence that these developments occurred in the same century as the American and French Revolutions, the beginning of the Industrial Revolution, and the initial solidification of a capitalistic economy. This is not the place to explore connections among the rise of aesthetics and the processes just mentioned. But we do well to realize that the philosophical issues we're considering are largely legacies of the eighteenth century.

It is no coincidence that in our day, when hard questions are being asked of liberal democracy, technological progress, and advanced capitalism, much philosophical effort is going into reexamining the very concept of art, clarifying the concepts used by art critics, and bringing aesthetics closer to aesthetic experience and artistic practice. One could speculate that aesthetics might be coming of age as one era ends and a new one begins. One need look no further than the writings of the economist Galbraith to realize the increasingly central role arts could play in our society. ${ }^{6}$ The more central arts become, the more need there could be for an aesthetics come of age. Provided we are not undone by voodoo economics and nuclear insanity, the current maturing of aesthetics could mark a social and cultural turnaround not envisioned by the confident aestheticians of the eighteenth century.

Among North American Christians with a "conversionist" bent," aesthetics is also coming of age. This event is noticeable in recent publications by Calvin Seerveld and Nicholas Wolterstorff. I find evidence of maturity in the ability of both men to get beyond pious slogans without hiding their Christian commitment. I also find evidence of maturity in their challenging traditional aesthetics and their joining current 
philosophical efforts at re-examining, clarifying, and making aesthetics practical.

\section{Seerveld's Modal Aesthetic Theory}

\section{Seerveld's essay "Modal Aesthetic} Theory" ${ }^{\prime \prime}$ tries to circumscribe the field of aesthetics. It does this by arguing for the presence of an aspect to the world and human experience, an aspect that would be properly called aesthetic and that could not be properly reduced to sensory, technical, logical or other aspects. Seerveld tries to make his case by appealing to art as evidence for the fact that there is an irreducible aesthetic mode. Thus Seerveld's article tries to specify and connect two of the "essentially contested" concepts in aesthetics today: "art" and "the aesthetic."

Though Seerveld describes a stalemate, his own approach to the problem of defining art is clearly more essentialist than operationalist. He proposes "allusiveness" and the distinctive feature that essentially characterizes all art and the entire aesthetic aspect. This move prompts a number of questions. Isn't "allusivenes' too elusive a concept to serve as the linchpin for an aesthetic theory? Is there anything allusive about what most aestheticians describe as aesthetic experiences and aesthetic qualities? ? $^{33}$

Seerveld's argument is not without problems. The main logical difficulty is that his argument begs the question. Seerveld's definition of art assumes the presence of an aesthetic aspect. Thus to cite art as evidence for the presence of an aesthetic aspect is simply to beg the question of whether there is an irreducible aspect properly called aesthetic.

Besides this logical difficulty, there is a larger theoretical issue at stake here. Seerveld calls this issue "the methodological problem of definition." "Essentialists" and "operationalists" have reached a stalemate over defining the nature of art, according to Seerveld. Essentialists take art to be a primary reality whose essential nature has to be posited rather than analyzed ad infinitum. Operationalists argue that, as a matter of fact, to try defining art's essential nature is to misconceive the concept of art. Two results of this misconceiving are definitions both too broad and too narrow as well as confusion of classificatory criteria for calling something art with evaluative criteria for calling good art. ${ }^{10}$

For example, Clive Bell takes significant form to be the defining property of any work of art. He thereby excludes many objects that others would consider works of art, and he leaves few ways to exclude many objects with significant form that no one would consider works of art. In addition, though presented as a necessary and sufficient condition for classifying objects as works of art, "significant form" actually functions in Bell's theory as a criterion for commending certain objects, such as the paintings of Cezanne, and condemning other objects, such as the sentimental, illustrative painting that dominated English taste in the early 1900's. ${ }^{11}$

Though Seerveld describes a stalemate, his own approach to the problem of defining art is clearly more essentialist than operationalist. He proposes "allusiveness" as the distinctive feature that essentially characterizes all art and the entire aesthetic aspect. This move prompts a number of questions. Isn't "allusiveness" too elusive a concept to serve as the linchpin for an aesthetic theory? ${ }^{12}$ Is there anything allusive about what most aestheticians describe as aesthetic experiences and aesthetic qualities ${ }^{13}$ Furthermore, does not Seerveld's proposal force him into problems similar to those noted in Clive Bell's theory? Isn't allusiveness avoided in many works of art such as paintings by Ellsworth Kelly? Would not many obviously allusive objects be improperly called works of art? And isn't Seerveld trying to hit both classifications and evaluations with one definitional stone? 


\section{Wolterstorff's Functional Philosophy of Art}

Unlike Seerveld's approach to defining art, Wolterstorff's is more operational than essentialist. Art in Action begins by describing works of art as "objects and instruments of action" that are "inextricably embedded in the fabric of human intention." 14 Though "universal to mankind," the arts have no single overriding purpose. They "play an enormous diversity of roles in human life."1s

At this point an essentialist critic could object that Wolterstorff is skirting the question of what art is by concentrating on what art does. But Wolterstorff does define what art is, even though he seeks $a$ definition suitable for the purpose of his discussion rather than the correct definition.

For those purposes Wolterstorff uses two definitions of art. First, "an art is a skill, a craft, a competence in making." This definition goes back to the Greco-Roman concepts of techne and ars. ${ }^{16}$ Second, Wolterstorff also employs a modern concept of art that groups together "music, poetry, drama, literary fiction, visual depiction, ballet and modern dance, film, and sculpture." 17 He has these eight phenomena in mind when he uses the term "(fine) art." "An art is a fine art in a given society," he says, "if in that society products of that art are regularly ... produced or distributed with disinterested contemplation as one of the primary intended public uses." 18

From an "array of interconnected concepts" about works of art Wolterstorff selects the following as most useful for his purposes: a work of art is "a product of one of the (fine) arts. ${ }^{19}$ He claims this definition will allow him not only to "speak of aesthetically poor works of art," and thus to avoid confusing classification with evaluation, but also to "speak of liturgical art," and thus to avoid excluding from the category of art certain objects that do not have disinterested contemplation as their primary intended public use.

There seems to be some fuzziness here in
Wolterstorff's otherwise lucid account. Although he wishes to challenge the modern tendency of tying art to aesthetic contemplation, his preferred definition of work of art obviously derives from that very tendency. Given his preferred definition, how can he avoid the following consequence. For him to call a piece of church music a work of art would be to say that this piece is a product of an art (music) whose products in our society are regulary produced or distributed for disinterested contemplation. If disinterested contemplation is not the primary intended public use of the piece in question, then why even bother to call it a work of art? Why not just call it a piece of church music or, perhaps, a liturgical composition? Again, given the apparent fact that much music in our society is used for entertaining, setting moods, and advertising commodities, but not for aesthetic contemplation, why bother to call a piece of topforty rock a work of art? Why not simply call it a piece of rock music? Quite apart from the matter of correctness, one could question the appropriateness of Wolterstorff's definitions for his own discussion.

I have been using Seerveld and Wolterstorff to illustrate the problem of defining art. On the one hand, we have noted problems tied to an essentialist assumption. If one assumes that a single feature such as allusiveness essentially characterizes all objects called works of art, then one's definition tends to become too broad, too narrow, and too confusing with respect to classifying and evaluating objects as works of art. On the other hand, we have noted problems tied to an operationalistic assumption. If one assumes that "art" is a word with numerous uses and a concept with various meanings, none of which is most nearly correct, and if one decides to use whatever concept seems appropriate to the discussion at hand, then one's definition tends to become so indefinite that at certain points the definition is no longer useful.

I suspect both sets of problems could be shown to be legacies of eighteenth-century 
aesthetics. Seerveld's philosophical tradition goes back to British empiricism, described by Saisselin as "an aesthetics for angels" prone to "the essentialist fallacy." Wolterstorff's philosophical tradition goes back to British empiricism, described by Saisselin as "an aesthetics for economists" prone to "the naturalistic fallacy" of confusing art with sensate nature. In both eighteenth-century cases, says Saisselin, "aesthetics is led away from the arts . .." in their historical nature. ${ }^{20}$

If we do not place concern for liberation and reconciliation first, then it is easy for our artistry and aesthetics to become complacent toward the real suffering and struggles taking place in today's society To counteract complacency, perhaps conversionist Christians should speak more often of concrete strategies for liberation.

During the nineteenth century, however, philosophers as diverse as Hegel and Comte began to insist on the historical and social character of art. Their insistence has helped bring aesthetics closer to the arts. Few serious philosophers of art today would overlook the fact that whatever art is, and whatever art does, it undergoes significant changes in history and belongs to specific societies. Both Seerveld and Wolterstorff acknowledge art's socio-historical character. Seerveld tends to interpret this character as a response to an abiding order, to "cosmogonic, structuring guidelines." 21 Wolterstorff tends to interpret this character as a factual given that elicits various responses. These tendencies will emerge more fully as I turn now from the problem of defining art to questions about arts in history and society.

\section{The Arts in History and Society}

Adapting a scheme suggested by Harold Osborne, we may distinguish three sorts of
Western theories about art in society. ${ }^{22}$ There are instrumental theories, derived in part from pragmatic interests. There are referential theories, derived in part from cognitive interests in art as a reflection or copy. And there are formalist theories, derived in part from an aesthetic interest in art.

We would be mistaken, however, to think that only instrumental theories speak to the roles of arts in society, or that only formalist theories speak to the aesthetic features of art. For example, though Wolterstorff has an instrumental theory of art, he pays close attention to the aesthetic qualities and merits of artworks. Though Seerveld has a more formalist theory of art, he tries to place the "artistic task" in the context not only of "aesthetic life" but also of contemporary society. The terms "instrumental" and "formalist" indicate certain emphases having historical weight rather than exclusive types having pure representatives. Interestingly enough, both Wolterstorff and Seerveld display considerable interest in art as a reflection. Wolterstorff writes at length about "the action of world-projection." ${ }^{23}$ Seerveld's "allusiveness" indicates a fundamental concern for references made within art. The one takes artistic reference to be an instrumental action. The other takes artistic reference to be a primary characteristic of "art-as-such."

\section{"Art-as-such," Culture, and Reconciliation}

Seerveld's notion of "art-as-such" has built into it some limitations, however, some of which can be found in other formalist approaches to art's place in history and society. Three limitations trouble me the most.

In the first place Seerveld speaks of the development of art-as-such as a "proper historical differentiation" having an "historically normative feature." 24 This seems to mean that fine art for aesthetic contemplation developed in Western society represents the best or preferrable shape for art to take. Backed by a conception of 
"cosmogonic structuring . . . which prompts ... the unfolding of creation's . . richness," such a claim suggests the theory that whatever is, or whatever has come to be, is right. Would Seerveld wish so easily to legitimize the status quo?

Seerveld's account of art's development is anchored in his understanding of the "cultural mandate." This understanding displays a second troubling limitation in his approach to art's place in history and society. I have no problems with saying that from the beginning of recorded history God has asked human beings to cultivate the earth to His praise. But I refuse to conclude directly from this statement that "art is one way for men and women to respond to the Lord's command to cultivate the earth, to praise His Name." 26 If sin and evil are as vexing as Seerveld claims they are, ${ }^{27}$ then the first point to be made is not that art is a way to honor God's request. Instead the point to be raised first is whether today artistic activities of any kind can contribute to the liberation and reconciliation for which all creatures continue to groan. If artistic activities can contribute, then how, and what sorts of artistic activities would be most strategic? If we do not place concern for liberation and reconciliation first, then it is easy for our artistry and aesthetics to become complacent toward the real suffering and struggles taking place in today's society. To counteract complacency, perhaps "conversionist" Christians should speak more often of concrete strategies for liberation.

When Seerveld does speak of such strategies, a third limitation appears. Explaining "obedient art," he writes: "A communion of Christian artists instituted to work under the new testamented ministry of reconciliation will break new ground, at sharp odds with the secular world ... To 'reconcile' means to pull out of unrighteous forming hands whatever they are busy with and bring it back to the Lord, back in line with his ordinances." 28 To my ears this explanation sounds uncomfortably close to the program of the Moral Majority-kick out the secular humanists! Might we be facing too facile an equation of the antithesis between good and evil with the distinction between Christian and unchristian? Seerveld himself recognizes that the Holy Spirit does not restrict his reconciling activities to the things done by people who call themselves Christians. Were these recognitions fully operative, however, greater emphasis might fall on Christians making contributions to contemporary culture and society and cooperating with those groups and individuals among whom the Spirit's activity is most evident. Perhaps the times in which we live are forcing alternative Christian organizations to turn into forces of reaction despite their stated intentions. In that case Calvinist conversionists should be reconsidering their cherished notions of the cultural mandate and the antithesis. ${ }^{29}$

\section{Liberation and the Institution of High Art}

Raising the question of strategy is a major contribution of Art in Action. In the chapter titled "Liberation" Wolterstorff writes:

So the question confronting the Christian struggling to act obediently . . . is the thoroughly concrete question of how, if at all, he or she should participate in our social institution of high art. On the way to answering this question the Christian may find it important to pose the abstract question: Is there a place in the Christian life ... for art as such? But answering Yes to that question leaves him far short of knowing how he should participate in the institution of high art as it finds shape in our society today. ${ }^{30}$

Wolterstorff's approach here corrects abstract attempts by some Calvinists to legitimize artistry by way of the cultural mandate. Rather than legitimize artistry, Wolterstorff develops a social theory posing critical questions. This development is a 
breakthrough in Christian aesthetics. Nevertheless, some reservations do need to be stated with respect to Wolterstorff's descriptions and conclusions concerning "high art."

Western society's institution of high art is described as "the characteristic ... patterns of action pertaining to the production, distribution, and use" of any artworks "used (in the way intended by artist or distributor) almost exclusively by the members of [our cultural] elite." ${ }^{31}$ Salient features of the institution are a separation of art from life, the immensity of diverse repertoire, an emphasis on aesthetic contemplation, the religion of liberating creativity, and an interiorizing of the artistic community. ${ }^{32}$ These features are accompanied by aesthetic impoverishment in everyday life. To Christians, Wolterstorff proposes a double strategy: for the sake of aesthetic excellence in cities, churches, and daily life, liberate life from high art's blinding spell; and, when participating in the institution of high art, assess priorities, struggle to integrate artistic goals and Christian commitment, and resist any claims for the ultimacy of art. ${ }^{33}$

Art is a social ${ }=$ cultural, and historical phenomenon as well as concept. It has gradually come into existence, it has acquired definite contours within certain societies, cultures, and historical phases, and it can acquire different contours as those societies, cultures, and historical phases change.

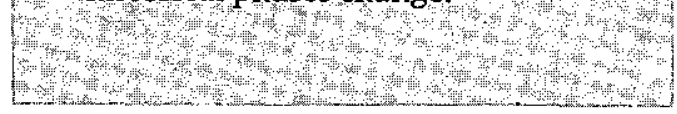

It is not readily apparent, however, why the institution of high art should trouble us. Wouldn't most of us prefer art's aesthetic use by intellectuals over self-aggrandizement by aristocratic patrons or indoctrination by an ecclesiastical hierarchy? Isn't there something profoundly democratic and enlightening about Western society's high art, in contrast to its "works of popular art," which are largely kitsch, and to its "works of the tribe," which function as commercial propaganda? Wouldn't Wolterstorff's descriptions of high art be more telling if they were set beside such features in our "low" art as the substitution of entertainment for life, the immensity of standardized repertoire, an emphasis on commercial success, the religion of passive conformity, and the heroizing of "stars"? Surely aesthetic squalor cannot be blamed on high art's spell, nor can aesthetic excellence be attained simply by disenchantment. Surely a critique of high art should not dispense with a critique of low art, nor should Christians be content with restrained participation that does nothing to revolutionize our society's entire institution of art.

Let me suggest that all our forms of art hang together in an economic subsystem within advanced capitalism. This subsystem effectively absorbs or marginalizes most serious artistic challenges to the status quo. At the same time the subsystem insures that most artworks serve to ratify the status quo. Traditionally aesthetic theory has played a key role in this subsystem, our society's institution of art. To penetrate that institution, aesthetic theory must resist being lured by "high art" into stressing consumption and educational status as defining factors in the institution. "Aesthetic contemplation" by an "intellectual elite" does occur in our society's institution of high art. But a critical aesthetics should push past these factors to the often destructive economic processes of production and distribution behind them. Despite Wolterstorff's discussion of "production, distribution, and use," his critique of high art stops short of the economic base and the unusual commodity character of all art in our society. It seems to me that only by exposing the economic underpinnings of art can we develop an aesthetic theory both comprehensive enough to explain how our entire institution of art has developed and penetrating enough to indicate what should be done with it. To begin such an account, I, 
for one, would turn to the work of Theodor W. Adorno and the Frankfurt Institute for Social Research. ${ }^{34}$

\section{Conclusion}

By now I hope we have come indirectly to three understandings about the nature of art. First, art is not something for which noninferential axioms and broad consensus hold, not even among Christian aestheticians of common persuasion. Second, both as a concept and as a phenomenon, art undergoes continual changes, some of which amount to redefinitions of art itself, and art undergoes these changes within various social institutions from which art itself cannot be extricated. Finally, art is elicitng from contemporary Christian scholars attempts at defining it and locating it that let it be illuminated by the light of Christ's liberating the entire world.

From these understandings I would derive the hypothesis with which I wish to conclude: Art is a social, cultural, and historical phenomenon as well as concept. It has gradually come into existence; it has acquired definite contours within certain societies, cultures, and historical phases; and it can acquire different contours as those societies, cultures, and historical phases change. In a word, art is a shifting constellation for which neither essentialist nor operationalist theories suffice.

\section{Notes}

Nicholas Wolterstorff, Reason Within the Bounds of Religion (Grand Rapids, MI: Eerdmans, 1976).

'See in this connection, Stephen Toulmin, Knowing and Acting (New York: Macmillan, 1976), pp. 143-206.

${ }^{3} \mathrm{G}$. Dickie, Aesthetics: An Introduction (New York: Pegasus, 1971), p. 1.

4P. O. Kristeller, "The Modern System of the Arts" (1951-1952). Reprinted in Renaissance Thought II (New York: Harper Torchbooks, 1965), pp. 163-227.

${ }^{\mathrm{S}} \mathrm{R}$. G. Saissellin, Taste in Eighteenth Century France (New York: Sytacuse University Press, 1965), p. 117.

'J. K. Galbraith, "The Market System and the Arts." In Economics and the Public Purpose (Boston: Houghton Mifflin, 1973), pp. 61-70.
'For a characterization of conversionist Christianity, see H. Richard Niebuhr, Christ and Culture (New York: Harper Torchbooks, 1951), pp. 190-229.

${ }^{\circ} \mathrm{C}$. Seerveld, Rainbous for the Fallen World (Toronto: Tuppence Press, 1980), pp. 104-137.

'Seerveld, pp. 105-109. Seerveld illustrates the problem by describing a debate between "neo-idealists" and "operationalists." In my discussion I have substituted "essentialist" for the term "neo-idealist."

${ }^{20}$ See in this connection Dickie, pp. 41-43, 69-108.

${ }^{1}$ Dickie, pp. 70-78.

${ }^{12} \mathrm{Cp}$. David A. Hoekema, "Elusive About Allusive," The Reformed Journal 31 (Sept. 1981) 9:22-25.

${ }^{13} \mathrm{Cp}$. Wolterstorff's comments in "Two Writers Engage in Rainbow Action," Vanguard 10 (Nov.-Dec. 1980) 6:4-5, 18-19.

${ }^{14}$ Nicholas Wolterstorff, Art in Action (Grand Rapids, MI: Eerdmans, 1980), p. 3. Hereafter cited as Art.

is Art, p. 4.

${ }^{16} \mathrm{Art}$, p. 37. An important question, however, is whether the Greek notion of techne actually resembles later concepts of craft and technique. Heidegger has argued that "techne signifies neither craft nor art, and not at all the technical in our present-day sense; it never means a kind of practical performance... Techne, as knowledge experienced in the Greek manner, is a bringing forth of begins . . out of concealedness and . . . into the unconcealedness of their appearance." Martin Heidegger, "The Origin of the Work of Art," in Poetry, Language, Thought, trans. Albert Hofstadter (New York: Harper Colophon Books, 1971), p. 59.

"Art, pp. 6, 7.

${ }^{18}$ Art, p. 37.

${ }^{19}$ Art, pp. 17, 18.

${ }^{20}$ Saissellin, pp. 117-34.

${ }^{21}$ Rainbows for the Fallen World, pp. 112-13.

${ }^{22} \mathrm{H}$. Osborne, Aesthetics and Art Theory: An Historical Introduction (New York: E. P. Dutton, 1970), pp. 17-24 and passim.

${ }^{23}$ Art, pp. 122-55.

${ }^{24}$ Seerveld, pp. 112-13.

${ }^{25}$ Seerveld, p. 110.

${ }^{26}$ Seerveld, p. 25.

${ }^{27}$ Seerveld, pp. 28-31.

${ }^{28}$ Seerveld, p. 39.

29Participants in the Arts Seminar have pointed out the sketchiness of my comments on the cultural mandate and the antithesis. Acknowledging their point, I want to express my intention to develop these comments at some later date.

${ }^{30} \mathrm{Art}, \mathrm{p} .117$.

${ }^{31}$ Art, p. 22.

${ }^{32}$ Art, pp. 24-63.

${ }^{33}$ Art, pp. 175-99.

34See Lambert Zuidervaart, Refractions: Truth in Adorno's Aesthetic Theory (Toronto, 1981), especially pp. 18-23, 37-62, 199-205. 